\title{
Evidence of traffic-related pollutant control in soil-based Sustainable Urban Drainage Systems (SUDS)
}

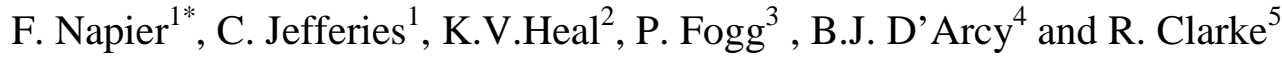 \\ 1 University of Abertay Dundee, Bell Street, Dundee, DD1 1HG, UK; c.jefferies@abertay.ac.uk; \\ f.napier@abertay.ac.uk \\ 2 University of Edinburgh, School of GeoSciences, Crew Building, West Mains Road, Edinburgh, EH9 3JN, UK; \\ Kate.Heal@ed.ac.uk \\ 3 Cambridge Environmental Assessments, ADAS Gleadthorpe, Medan Vale, Mansfield, Nottinghamshire, NG20 \\ 9PF,UK; Paul.Fogg@cea-res.co.uk \\ 4 Central Advisory Unit, Scottish Environment Protection Agency, Perth PH2 OPA, UK; \\ Brian.Darcy@sepa.org.uk \\ 5 Scottish Environment Protection Agency, Clearwater House, Heriot Watt Research Park, Avenue North, \\ Riccarton, Edinburgh, EH14 4AP, UK
}

*Corresponding author, e-mailf.napier@abertay.ac.uk

\begin{abstract}
SUDS are being increasingly employed to control highway runoff and have the potential to protect groundwater and surface water quality by minimising the risks of both point and diffuse sources of pollution. While these systems are effective at retaining polluted solids by filtration and sedimentation processes, less is known of the detail of pollutant behaviour within SUDS structures. This paper reports on investigations carried out as part of a coordinated programme of controlled studies and field measurements at soft-engineered SUDS undertaken in the UK, observing the accumulation and behaviour of traffic-related heavy metals, oil and PAHs. The field data presented were collected from two extended detention basins serving the M74 motorway in the south-west of Scotland. Additional data were supplied from an experimental lysimeter soil core leaching study. Results show that basin design influences pollutant accumulation and behaviour in the basins. Management and/or control strategies are discussed for reducing the impact of traffic-related pollutants on the aqueous environment.
\end{abstract}

\section{KEYWORDS}

Detention basins; metals; oil; soil; soil water, SUDS

\section{INTRODUCTION}

As point source emissions of pollutants are increasingly brought under control, diffuse sources have emerged as a serious and continuing threat to the aquatic environment (SEPA, 1999). Highway runoff is a major contributor to diffuse pollution and is the source of many pollutants that can adversely affect the water quality and ecology of receiving waters (Gray, 2004). Levels of traffic-related persistent pollutants such as zinc and copper continue to rise in line with increasing traffic volumes (Napier and Jefferies, 2005), and road traffic has now become the largest single source of PAHs to the UK atmosphere (NAEI). The EU Water Framework Directive (2000/60/EC) requires the UK to control diffuse sources of priority pollutants with the goal of protecting water bodies, including groundwater. SUDS are being increasingly employed to control highway runoff and have the potential to protect groundwater and surface water quality by minimising the risks of both point and diffuse 
sources of pollution. While these systems are effective at retaining polluted solids by filtration and sedimentation processes (CIRIA, 2000), less is known of the detail of pollutant behaviour within SUDS structures.

The varying nature of highway pollutants and the physical, chemical and biological processes they undergo in the environment means that they can be expected to behave in very different ways. Environmental conditions vary between SUDS. Sediment-bound pollutants in swales and detention basins are exposed to light and air while, in contrast, pollutants bound to aquatic pond sediments face low light levels and anoxic conditions. Consequently there will be differences in pollutant fate, making the selection of the best control method difficult. While guidance is available on how to combine and size SUDS facilities in relation to expected flow volumes, data do not yet exist to allow similar decisions to be made regarding pollutant treatment potential. A particular area of concern is the vertical movement of contaminants in swales and detention basins, as this will determine potential risks to groundwater.

A co-ordinated programme of controlled studies and field measurements at soft-engineered SUDS was undertaken in the UK, observing the accumulation and behaviour of traffic-related heavy metals, oil and PAHs. The project involved collaboration between the researchers, the Scottish Environment Protection Agency, the Highways Authority and the Environment Agency in England. This paper reports on the investigations carried out to assess the risk to groundwater posed by the pollutants accumulating in SUDS, and the fate of key pollutants in the soil. On the basis of that data, a rationale is provided for selecting the optimum management and/or control strategies for reduction of the impact of these pollutants on the aqueous environment to be developed.

\section{METHOD}

A range of SUDS types were investigated, including extended detention basins, retention ponds and swales, as shown in Table 1 . The careful selection of complementary field sites has allowed comparisons to be made based on SUDS type. Controlled, small-scale studies using specially constructed swales, soil core lysimeters (three soil types) and batch soil experiments have all provided data on the accumulation, degradation, leaching behaviour and factors controlling these processes for PAHs, heavy metals and oils.

Extensive data have been collected in this multi-component project, and interpretation is ongoing. While it is not possible to give full details of each study in this paper, most of the major findings to date are illustrated by the results of the sampling carried out at two motorway detention basins. Accordingly, this paper focuses on the investigations carried out at these sites, with reference to relevant corroborating evidence from the lysimeter soil core study. Full details of the other study components and a full synthesis of all the data and findings are in Jefferies et al. (2008).

\section{M74 Basins}

The M74 basins have been in operation for approximately seven years. They receive runoff from the M74 motorway, a major rural highway with free-flowing traffic. At the locations monitored, the motorway is six lanes wide, with an average annual daily traffic (AADT) of 13,000 . Both basins drain approximately $18,000 \mathrm{~m}^{2}$ of carriageway, and receive piped inflow via roadside filter drains. 
Table 1. Study components

\begin{tabular}{|c|c|c|c|}
\hline Study component & AADT* & Description & Nature of sampling \\
\hline $\begin{array}{l}\text { Field Study } \\
\text { M74 Detention } \\
\text { Basin 27A } \\
\text { SW Scotland }\end{array}$ & 13,000 & $\begin{array}{l}\text { Grassed basin incorporating small } \\
\text { lined pool. Piped inflow. }\end{array}$ & $\begin{array}{l}\text { Soil samples at different } \\
\text { locations and depths. } \\
\text { Submerged sediment } \\
\text { samples at different } \\
\text { locations. }\end{array}$ \\
\hline $\begin{array}{l}\text { M74 Detention } \\
\text { Basin 29A } \\
\text { SW Scotland }\end{array}$ & 13,000 & $\begin{array}{l}\text { Grassed basin incorporating small } \\
\text { lined pool. Piped inflow. }\end{array}$ & $\begin{array}{l}\text { Roadside filter drain } \\
\text { samples. } \\
\text { Soil samples at different } \\
\text { locations and depths. } \\
\text { Soil water samples. } \\
\text { Submerged sediment } \\
\text { samples at different } \\
\text { locations and depths. }\end{array}$ \\
\hline $\begin{array}{l}\text { M74 Retention } \\
\text { Ponds 33A \& B } \\
\text { SW Scotland }\end{array}$ & 13,000 & $\begin{array}{l}\text { Treatment ponds in sequence }\left(1^{\text {st }}\right. \\
\text { lined, } 2^{\text {nd }} \text { unlined). Piped inflow. }\end{array}$ & $\begin{array}{l}\text { Submerged sediment } \\
\text { samples at different } \\
\text { locations and depths }\end{array}$ \\
\hline $\begin{array}{l}\text { M74 Retention } \\
\text { Ponds 40A \& B } \\
\text { SW Scotland }\end{array}$ & 13,000 & $\begin{array}{l}\text { Treatment ponds in sequence }\left(1^{\text {st }}\right. \\
\text { lined, } 2^{\text {nd }} \text { unlined). Piped inflow. }\end{array}$ & $\begin{array}{l}\text { Submerged sediment } \\
\text { samples at different } \\
\text { locations }\end{array}$ \\
\hline $\begin{array}{l}\text { M42 Hopwood MSA } \\
\text { Central England }\end{array}$ & & $\begin{array}{l}\text { SUDS treatment train for runoff } \\
\text { from HGV park (sheet flow). } \\
\text { Train comprises gravel filter strip, } \\
\text { grass filter strip, gravel filter } \\
\text { trench plus two treatment ponds }\end{array}$ & $\begin{array}{l}\text { Soil samples from grass } \\
\text { filter strip, different } \\
\text { locations and depths }\end{array}$ \\
\hline $\begin{array}{l}\text { A8000 swale } \\
\text { Edinburgh }\end{array}$ & 30,000 & $\begin{array}{l}\text { Roadside swale receiving both } \\
\text { piped and sheet inflow }\end{array}$ & $\begin{array}{l}\text { Soil samples at different } \\
\text { locations and depths }\end{array}$ \\
\hline $\begin{array}{l}\text { A90 roadside grass } \\
\text { verge, Edinburgh }\end{array}$ & 20,000 & $\begin{array}{l}\text { Grassed verge receiving road } \\
\text { spray }\end{array}$ & $\begin{array}{l}\text { Soil samples at different } \\
\text { locations and depths }\end{array}$ \\
\hline $\begin{array}{l}\text { Experimental Studie } \\
\text { Experimental swales }\end{array}$ & & $\begin{array}{l}\text { Specially constructed swales } \\
\text { dosed with pollutants and } \\
\text { irrigated }\end{array}$ & $\begin{array}{l}\text { Leachate samples plus } \\
\text { destructive soil sampling }\end{array}$ \\
\hline Soil core lysimeters & & $\begin{array}{l}\text { Soil cores (volume } 0.11 \mathrm{~m}^{3} \text { ) dosed } \\
\text { with pollutants and irrigated }\end{array}$ & $\begin{array}{l}\text { Leachate samples plus } \\
\text { destructive soil sampling }\end{array}$ \\
\hline $\begin{array}{l}\text { Lab-based batch } \\
\text { degradation study }\end{array}$ & & $\begin{array}{l}\text { Soil samples dosed with oil and } \\
\text { PAHs and incubated under } \\
\text { various conditions }\end{array}$ & Soil samples \\
\hline
\end{tabular}

*annual average daily traffic based on 7-day averages 
The detention basins vary in various design details, but both consist of an unlined grass basin bisected by a small pond. The layout of each is shown in Figure 1. Inflow at 27A is conveyed along a narrow swale-like channel to the pond. As water level in the pond rises, it spills over into the outlet channel, which is separated from the inlet by a grassed bund. In extreme events, the pond overflows on the far side into an overflow basin, and visual inspection found evidence of this occurring.

Inflow at 29A enters directly into a broad basin. As this basin fills, flow eventually spills into the pond. As the pond fills, the design intention is for water to flow into the outlet basin and on to the outlet. However, visual inspection of the outlet showed no evidence of regular flow.

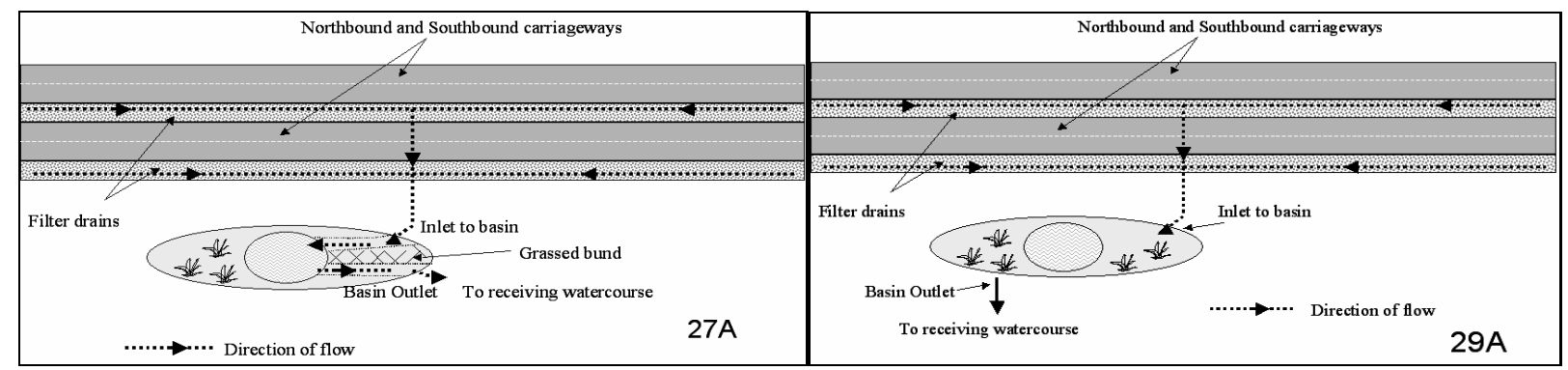

Figure 1. Layout of M74 detention basins 27A and 29A

The sampling strategy at the basins was designed to follow the inflow treatment sequence, i.e. inlet basin basin pond outlet basin. At Basin 29A, this included sediment from the upstream filter drain, and soil water. The pattern of soil and sediment sampling at the basins is illustrated in Figure 2.
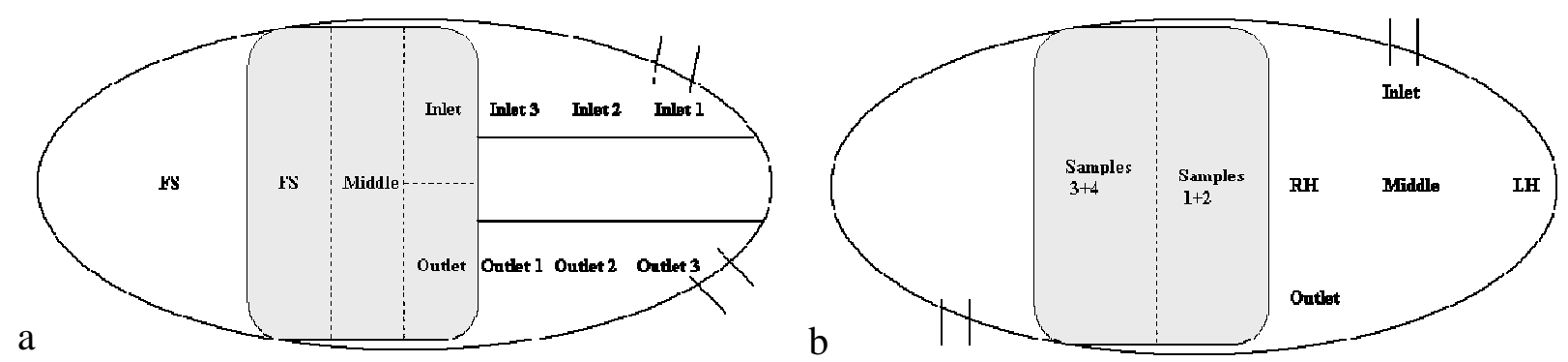

Figure 2. Sampling locations at Basins 27A (a) and 29A (b). Shaded area represents pond .

The samples were collected in the period January-June 2007. Soil samples from both basins were collected from two depths $(0-10 \mathrm{~cm}$ and $10-20 \mathrm{~cm})$ at each location, using a hand trowel. Sediment samples were collected from the ponds, following the pattern shown in Figure 2. Multiple samples (from two depths at 29A, one depth at 27A) were collected from each pond section and bulked to form a composite sample for each section.

Soil water samples from 29A were collected using porous suction-cup lysimeters (see Fig 3). A total of 29 suction samplers were installed across the inlet basin at a depth of $0.9 \mathrm{~m}$. On each of four sampling occasions, between March and June 2007, the soil water collected by these samplers was bulked to give a single composite sample.

Samples of sediment were collected from six separate locations along a $50 \mathrm{~m}$ stretch of the filter drain serving Basin 29A. At each location, the trench was excavated using a small digger, and the material removed was deposited on plastic sheeting. Random samples were collected and sieved $(5 \mathrm{~mm})$ into a plastic bucket. A very small amount of water was used to 
wash the finer sediment off the stone chips, and the resulting sludge formed a composite sample. Sediment from three catchpits was also sampled manually using a plastic scoop.
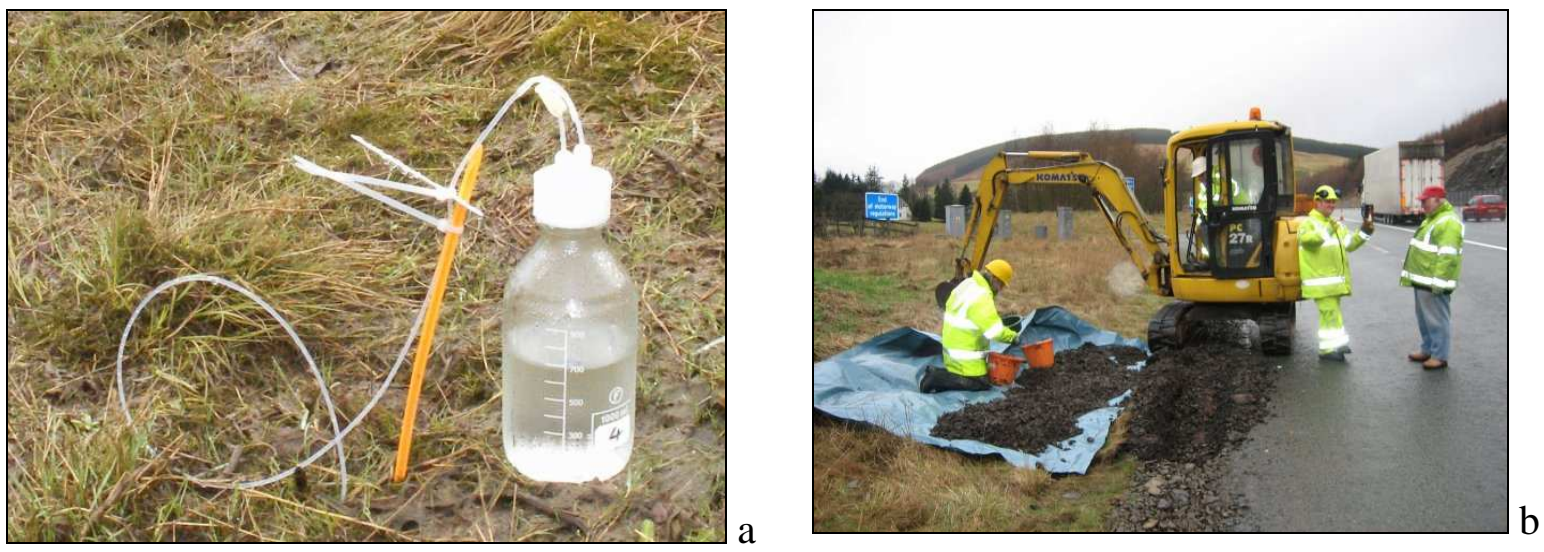

Figure 3. Soil water collection (a) and filter drain sediment sampling (b) at Basin 29A

\section{Lysimeter soil core study}

The lysimeter soil core study was designed to measure the immobilisation and degradation of priority pollutants in soft engineering SUDS and assess any leaching potential.

Soil core lysimeters $0.6 \mathrm{~m}$ deep (three replicate cores of three soil types selected as representative sand, silt and clay soils) and specially constructed SUDS lysimeters (three replicate cores comprising layers of gravel, sand and a top layer of biologically active topsoil) were dosed with a single application of PAH, TPH and metals. The loading applied is given in Table 3, and is representative of typical contaminant concentrations in highway runoff. The cores were then irrigated with water over a 135-day period (volume based on data for Scottish rainfall), and the drainage water collected for analysis (as shown in Figure 4.). At the end of the study period, the cores were destructively sampled and concentrations of each determinand at different depths were measured.
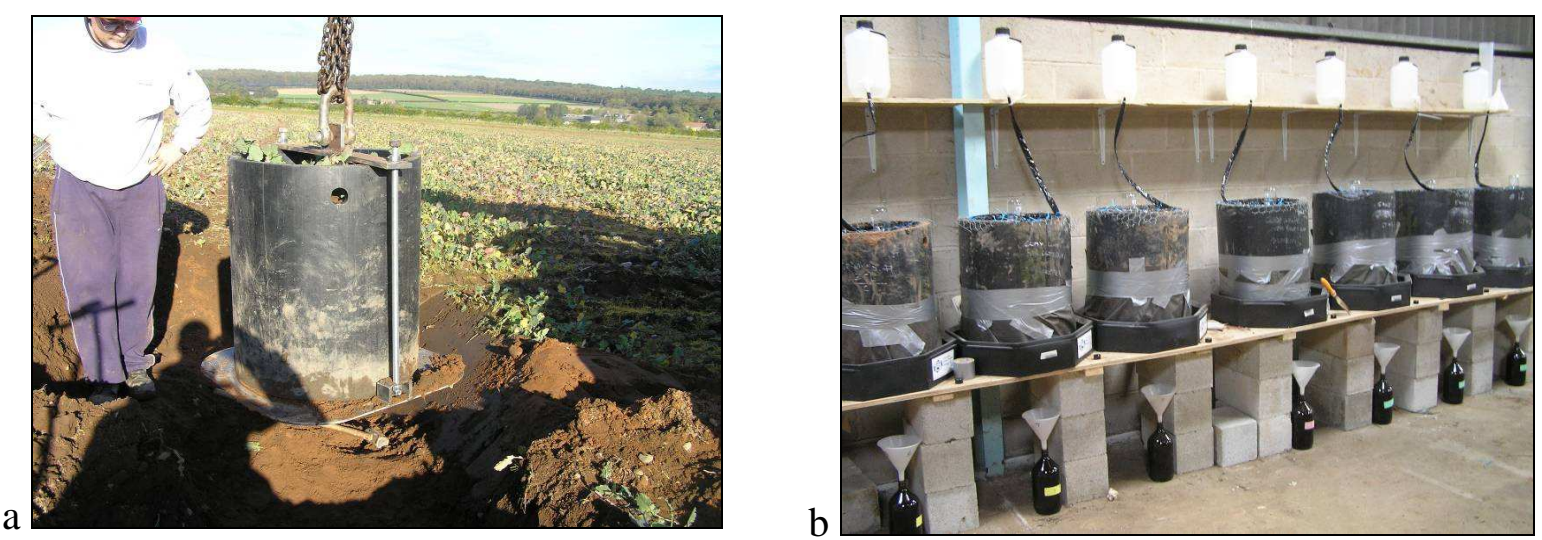

Figure 4. Soil core collection (a) and leaching study (b) 


\section{RESULTS AND DISCUSSION}

Table 5 shows the results of analysis of soil and sediment sampling carried out at the basins. The results of the the soil water sampling are given in Table 2. To allow a comparison of overall contamination between the basins, the volume of soil in each basin was estimated and used with the measured pollutant calculations to derive average values (for full method of calculation see Jefferies et al., 2008). Sediment concentrations from each pond were also averaged to allow comparison. The results are given in Table 4.

Table 2. Basin 29A soil water analysis (* concentration below reporting limit)

\begin{tabular}{|c|c|c|c|c|c|c|c|}
\hline $\begin{array}{c}\text { Date } \\
\text { sampled }\end{array}$ & $\mathrm{Cd}$ & $\mathrm{Cu}$ & $\mathrm{Pb}$ & $\mathrm{Ni}$ & $\mathrm{Zn}$ & TPH & $\begin{array}{l}\text { Total } \\
\text { PAH }\end{array}$ \\
\hline & $\mathrm{mg} \mathrm{l}^{-1}$ & $\mathrm{mg} \mathrm{l}^{-1}$ & $\mathrm{mg} \mathrm{l}^{-1}$ & $\mathrm{mg} \mathrm{l}^{-1}$ & $\mathrm{mg} \mathrm{l}^{-1}$ & $\mathrm{mg} \mathrm{l}^{-1}$ & $\mu g 1^{-1}$ \\
\hline $23 / 03 / 07$ & $*$ & 0.001 & $*$ & 0.003 & $*$ & $*$ & 0.33 \\
\hline $31 / 03 / 07$ & $*$ & 0.009 & 0.002 & 0.003 & 0.010 & 0.2 & 0.99 \\
\hline $11 / 05 / 07$ & $*$ & 0.013 & 0.001 & 0.003 & 0.010 & $*$ & 0.16 \\
\hline $29 / 06 / 07$ & $*$ & 0.009 & 0.002 & 0.211 & 0.020 & $0 . .1$ & No sample \\
\hline
\end{tabular}

Table 3. Results of mass balance calculations for selected pollutants in the soil core lysimeters

\begin{tabular}{cccc}
\hline Pollutant & $\begin{array}{c}\text { Total loading applied } \\
\text { /lysimeter } \\
\mathrm{mg}\end{array}$ & $\begin{array}{c}\text { \% applied pollutants } \\
\text { measured in drainage } \\
\text { water }^{1}\end{array}$ & $\begin{array}{c}\text { \% applied pollutants } \\
\text { retained or degraded in } \\
\text { soil cores }^{2}\end{array}$ \\
\hline Total PAH & 137 & 0.06 & 99.94 \\
$\mathrm{TPH}$ & 55000 & 0.07 & 99.93 \\
$\mathrm{Cu}$ & 163 & 0.45 & 99.55 \\
$\mathrm{Zn}$ & 2730 & 0.31 & 99.69
\end{tabular}

${ }^{1}$ value represents the maximum percentage pass-through for any soil type, which was measured in the clay lysimeters.

${ }^{2}$ value represents the minimum percentage for any soil type, which was measured in the clay lysimeters.

Table 4. Average basin soil and pond sediment pollutant concentrations (dry weight concs.)

\begin{tabular}{lrrrrrrr}
\hline & $\mathrm{Cd}$ & $\mathrm{Cu}$ & $\mathrm{Pb}$ & $\mathrm{Ni}$ & $\mathrm{Zn}$ & $\begin{array}{r}\text { TPH } \\
\text { Total } \\
\text { PAH }\end{array}$ \\
\hline & & & & & & $\mathrm{mg} \mathrm{kg}^{-1}$ \\
Filter drain (excluding catchpits) & 0.25 & 66 & 43 & 44 & 388 & 2563 & 9.5 \\
27A inlet and outlet channel soil & 0.19 & 44 & 28 & 48 & 160 & 888 & 5.6 \\
27A pond sediment & 0.40 & 109 & 60 & 43 & 386 & 2980 & 7.9 \\
29A inlet basin soil & 0.20 & 40 & 32 & 35 & 218 & 914 & 4.7 \\
29A pond sediment & 0.15 & 21 & 25 & 32 & 127 & 1414 & 2.3 \\
\hline
\end{tabular}

\section{Pollutant accumulation}

Soil concentrations at the basin inlets (given in Table 5) were mostly higher than average values for sediments found in the filter drain (see Table 4), implying accumulation over time in basin soils. In general, the soil pollutant concentrations decreased with distance from inlet and with depth as demonstrated for zinc in Figure 5. Figure 5 also demonstrates the differing patterns of pollutant accumulation within the individual basins. Pollutant concentrations in the upper soil layer at the inlet of 29A were almost double those at 27A probably reflecting the different inlet designs of the basins. At 29A, inflow velocity quickly dissipates as flow enters the broad basin, depositing contaminated sediments close to the inlet. Inflow velocity at $27 \mathrm{~A}$ is maintained longer in the narrow inlet channel, allowing sediments to be transported further. This theory is supported by a comparison of pond sediment pollutant concentrations at both basins in Table 4 . There was a noticeable difference in soil and pond sediment quality 
Table 5. Analysis results for soil and sediment sampling at Basins 27A and 29A (dry weight concs.) (*concentration below detection limit)

\begin{tabular}{|c|c|c|c|c|c|c|c|}
\hline & $\mathrm{Cd}$ & $\mathrm{Cu}$ & $\mathrm{Pb}$ & $\mathrm{Zn}$ & $\mathrm{pH}$ & TPH & Total PAH \\
\hline \multicolumn{8}{|l|}{ Basin 27A } \\
\hline Basin soil & $\mathrm{mg} \mathrm{kg}^{-1}$ & $\mathrm{mg} \mathrm{kg}^{-1}$ & $\mathrm{mg} \mathrm{kg}^{-1}$ & $\mathrm{mg} \mathrm{kg}^{-1}$ & & $\mathrm{mgkg}^{-1}$ & $\mathrm{mg} \mathrm{kg}^{-1}$ \\
\hline Inlet (1) Upper & 0.4 & 155 & 73 & 562 & 7.7 & 3607 & 12.19 \\
\hline Inlet (1) Lower & 0.2 & 60 & 32 & 211 & 8.2 & 1856 & 5.01 \\
\hline Inlet (2) Upper & 0.4 & 116 & 58 & 395 & 7.5 & 1947 & 7.42 \\
\hline Inlet (2) Lower & 0.2 & 43 & 29 & 159 & 7.6 & 769 & 3.36 \\
\hline Inlet (3) Upper & 0.3 & 67 & 40 & 246 & 7.4 & 1591 & 6.23 \\
\hline Inlet (3) Lower & 0.1 & 22 & 19 & 89 & 7.5 & 452 & 2.20 \\
\hline Outlet (1) Upper & 0.2 & 30 & 25 & 118 & 7.4 & 623 & 19.12 \\
\hline Outlet (1) Lower & 0.1 & 24 & 14 & 69 & 7.7 & 404 & 5.39 \\
\hline Outlet (2) Upper & 0.1 & 20 & 20 & 79 & 7.3 & 228 & 2.01 \\
\hline Outlet (2) Lower & 0.1 & 19 & 15 & 74 & 7.5 & 309 & 1.67 \\
\hline Outlet (3) Upper & 0.1 & 21 & 19 & 85 & 7.3 & 337 & 2.14 \\
\hline Outlet (3) Lower & 0.2 & 17 & 19 & 68 & 7.4 & 161 & 1.74 \\
\hline FS Upper & 0.1 & 18 & 21 & 80 & 7.3 & 205 & 2.95 \\
\hline FS Lower & 0.1 & 15 & 19 & 65 & 7.4 & 124 & 1.53 \\
\hline \multicolumn{8}{|l|}{ Pond sediment } \\
\hline Inlet $(\mathrm{P})$ & 0.5 & 136 & 66 & 475 & 7.1 & 4400 & 10.97 \\
\hline Outlet (P) & 0.4 & 90 & 52 & 312 & 6.9 & 2634 & 6.78 \\
\hline Middle (P) & 0.4 & 124 & 68 & 450 & 7.0 & 2753 & 7.27 \\
\hline $\mathrm{FS}(\mathrm{P})$ & 0.3 & 85 & 53 & 305 & 7.0 & 2134 & 6.58 \\
\hline \multicolumn{8}{|l|}{ Basin 29A } \\
\hline \multicolumn{8}{|l|}{ Filter drain } \\
\hline 1 & 0.25 & 64 & 43 & 376 & 8.9 & 3718 & 11.94 \\
\hline 2 & 0.21 & 52 & 34 & 274 & 8.7 & 1756 & 5.29 \\
\hline 3 & 0.20 & 62 & 45 & 379 & 8.9 & 2687 & 8.02 \\
\hline 4 & 0.31 & 84 & 51 & 528 & 9.3 & 2361 & 12.10 \\
\hline 5 & 0.29 & 80 & 50 & 459 & 9.2 & 2423 & 11.87 \\
\hline 6 & 0.21 & 53 & 35 & 315 & 9.2 & 2435 & 7.52 \\
\hline Catchpit 1 & 0.18 & 37 & 22 & 160 & 8.9 & 1000 & 2.37 \\
\hline Catchpit 2 & 0.35 & 83 & 53 & 423 & 9.0 & 7426 & 15.07 \\
\hline Catchpit 3 & 0.43 & 107 & 56 & 590 & 8.2 & 6002 & 25.40 \\
\hline \multicolumn{8}{|l|}{ Basin soil } \\
\hline Inlet Upper & 0.58 & 198 & 107 & 1050 & 7.7 & 4869 & 16.71 \\
\hline Inlet Lower & 0.31 & 51 & 37 & 280 & 8.7 & 1625 & 5.28 \\
\hline Middle Upper & 0.20 & 40 & 34 & 219 & 8.4 & 868 & 6.65 \\
\hline Middle Lower & 0.11 & 19 & 24 & 86 & 8.1 & 347 & 5.87 \\
\hline RH Upper & 0.15 & 20 & 25 & 119 & 7.7 & 340 & 2.13 \\
\hline RH Lower & 0.13 & 21 & 18 & 74 & 7.7 & 134 & 1.59 \\
\hline LH Upper & 0.22 & 38 & 34 & 218 & 7.8 & 808 & 4.38 \\
\hline LH Lower & 0.11 & 16 & 20 & 85 & 8.2 & 322 & 3.06 \\
\hline Outlet Upper & 0.10 & 8 & 18 & 63 & 7.0 & 127 & 1.64 \\
\hline Outlet Lower & 0.10 & 8 & 15 & 57 & 7.3 & 70 & 1.54 \\
\hline FS Upper & 0.13 & 18 & 22 & 102 & 7.4 & 190 & 1.64 \\
\hline FS Lower & $*$ & 13 & 17 & 74 & 7.7 & 127 & 1.60 \\
\hline \multicolumn{8}{|l|}{ Pond sediment } \\
\hline 1 & 0.19 & 26 & 29.7 & 155 & 7.0 & 142 & 1.95 \\
\hline 2 & 0.15 & 23 & 25.5 & 156 & 7.0 & 1387 & 2.31 \\
\hline 3 & 0.10 & 9 & 17.8 & 59 & 7.2 & 182 & 1.63 \\
\hline 4 & 0.16 & 25 & 28.2 & 138 & 6.9 & 3946 & 3.34 \\
\hline
\end{tabular}


between the basins. At 29A, most pollutant concentrations in the pond sediments were lower than the average soil values, with the exception of TPH. However, at 27A, pollutant concentrations in the pond sediment were double the calculated soil averages. Comparing both basin sediment qualities, 27A pond sediments had pollutant concentrations consistently higher than those at 29A; up to five times higher in the case of copper. As the basins receive similar loadings, and both have filter drains upstream, any difference must be a result of differences in basin design. It seems likely that the higher contaminant concentrations in the pond sediment at $27 \mathrm{~A}$ were a result of more contaminated sediments reaching the pond.
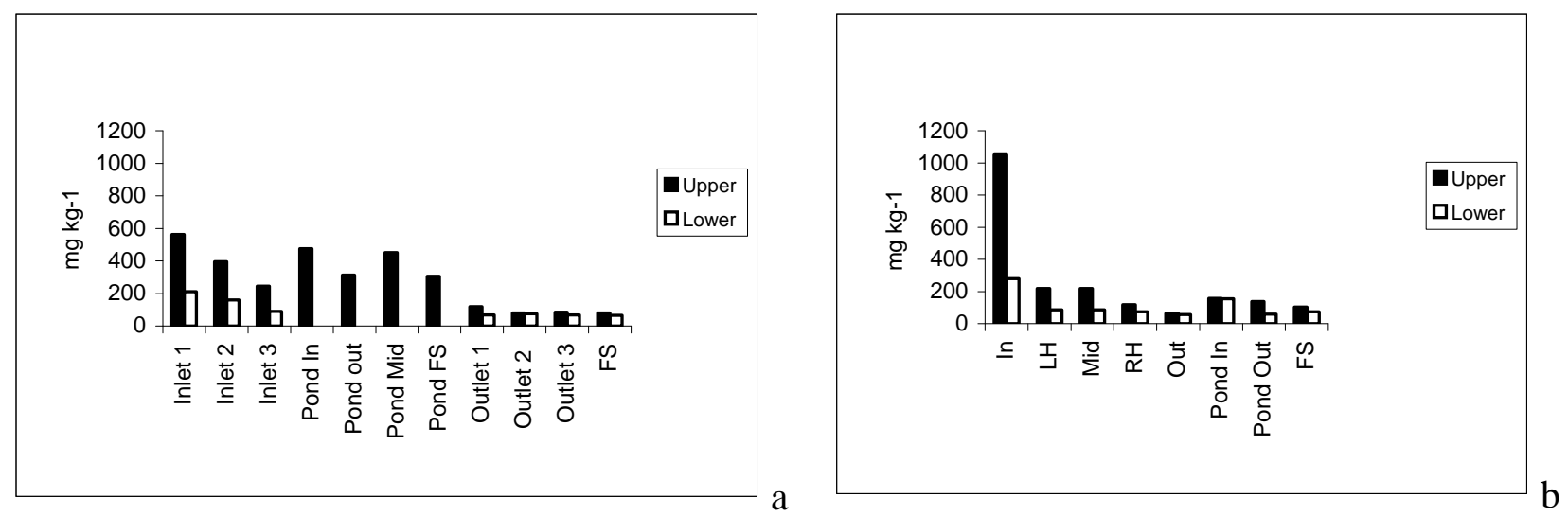

Figure 5. Zinc concentrations (dry weight) measured at Basins 27A (a) and 29A (b)

The data in Table 5 show that, despite pollutant hotspots, average soil pollutant concentrations across the basins were very similar.

\section{Submerged sediments}

The field study showed that the TPH and total PAH concentrations in the submerged sediments in the basin ponds are substantially higher than in the soil in the adjacent basins which dry out between rainfall events. Results show that while soil pollutant concentrations reduced with distance from inlet, concentrations then increased in the pond sediment. This pattern was observed for the metal pollutants also, but is most pronounced for the organic pollutants, as illustrated by TPH in Figure 6. This suggests that degradation of the organic
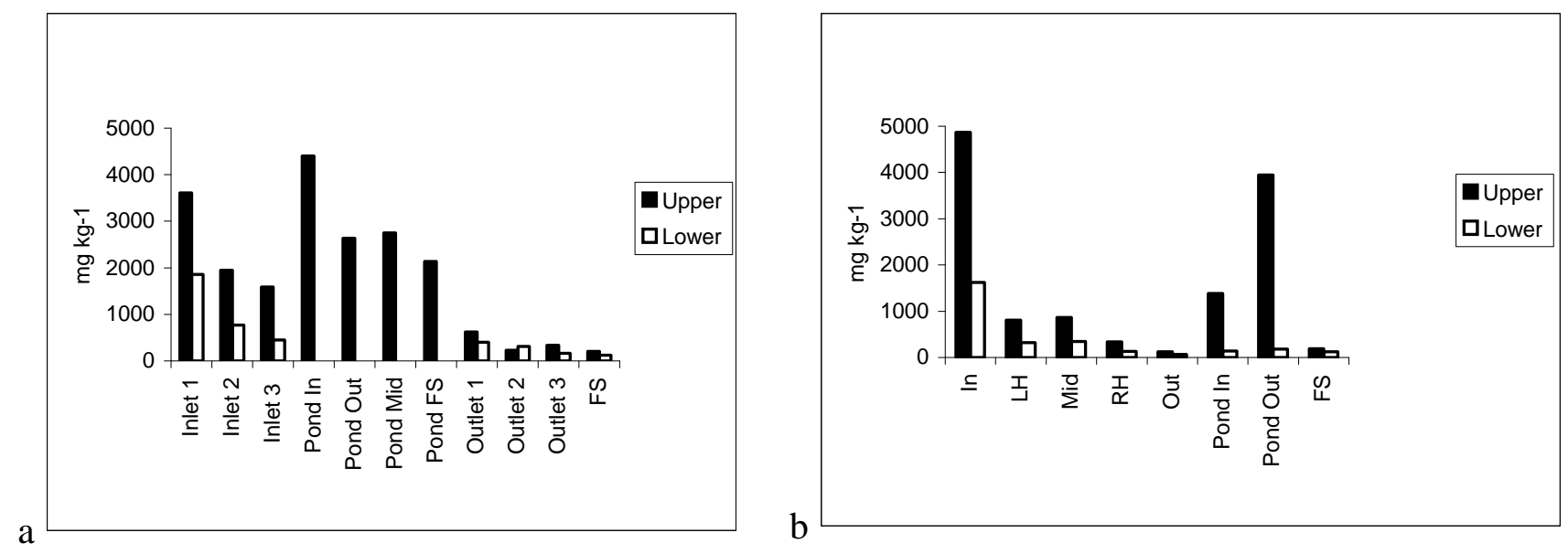

Figure 6. TPH concentrations (dry weight) measured at Basins 27A (a) and 29A (b) 
pollutants in the submerged sediments is slower than in the exposed soil. A similar pattern occurred in the filter drain, where the average TPH concentration measured in the submerged sediment in the catchpits (4809 $\mathrm{mg} \mathrm{kg}^{-1}$ ) was almost double the average from the rest of the filter drain $\left(2563 \mathrm{mg} \mathrm{kg}^{-1}\right)$.

\section{Pollutant movement}

At the basins, soil was sampled at two depths. At all sampling locations, higher concentrations were found in the top $10 \mathrm{~cm}$ of soil. In general, the magnitude of the vertical change in soil concentration measured at the basins decreased with distance from the inlet. Traffic-related metals $(\mathrm{Cu} / \mathrm{Pb} / \mathrm{Zn})$ were strongly correlated in the upper and lower soil layers at the basin inlets $\left(\mathrm{R}^{2}>0.99\right)$, but these correlations decreased in strength with distance from the inlet, suggesting that the lower concentrations in the $10-20 \mathrm{~cm}$ layers were not simply a measurement of background levels.

One explanation for the change in vertical concentration is sediment accumulation over time, with later deposits being more contaminated than earlier deposits. However, it is extremely unlikely that $20 \mathrm{~cm}$ of soil has accumulated in the basins in the seven years since their construction, especially with filter drains upstream. A more likely explanation is the downward migration of pollutants through the soil. However, evidence from the soil core lysimeter suggests that any downward migration of pollutants occurs slowly. The lysimeter study was conducted over a 4-month period, and destructive soil sampling at the end of the study showed that $>99 \%$ of the applied metal pollutants were retained in the top $10 \mathrm{~cm}$ of soil, with $<0.45 \%$ leaching through the $0.6 \mathrm{~m}$ soil cores. In the case of the organic pollutants, only $<0.07 \%$ of the organic pollutants leached through the cores, with the remainder either degraded or retained in the top $10 \mathrm{~cm}$ of soil. Nevertheless as pollutants accumulate in soil in soft engineering SUDS over time, it is possible that more downward movement could occur. However, analysis of soil water from Basin 29A shows very low pollutant concentrations at $0.9 \mathrm{~m}$, even after seven years in operation.

\section{Implications for SUDS design}

Evidence from this study suggests that the top $10 \mathrm{~cm}$ of soil is very important in pollutant attenuation. The soil core lysimeter study showed that most of the applied pollutants which were retained in the soil cores were found in the upper $10 \mathrm{~cm}$ of soil. This information is supported by field results where pollutant concentrations were consistently higher in upper than lower soil layers. However, in the construction of some infiltration devices (eg soakaways) the topsoil is normally removed and runoff is discharged into underlying formations. It may be appropriate to revisit this practice to improve pollutant removal performance and also minimise the risk of groundwater contamination.

The results from the basins suggest that basin design should be 'wide and shallow' rather than 'narrow and deep' to allow adequate time for sediment retention. The difference in pond sediment quality between the basins shows the important role of upstream sediment removal in minimising the subsequent contamination of aquatic sediments, especially by organic pollutants. Additionally, the difference in contamination levels observed in soil and sediment at each basin indicates that organic pollutants receive more effective treatment in exposed soil than in submerged sediments. This evidence suggests that it is desirable that highway runoff should pass through a swale or detention basin prior to entering a pond. Passing over / through vegetation and soil will enhance the removal of pollutants from the runoff and the control of pollution. 


\section{CONCLUSIONS}

The key findings from the data presented can be summarised as follows:

- Inlet design influenced the pattern of contamination in the basin soils, but did not affect total average soil pollutant concentrations. However, inlet design had a noticeable effect on average sediment quality in the basin ponds.

- The degradation of organic pollutants in submerged sediments is slower than in exposed soil.

- Any downward movement of pollutants through the soil appears to be slow, with most pollutants retained in the top $10 \mathrm{~cm}$ of soil.

- The results highlight the importance of sediment removal from contaminated runoff to minimise subsequent contamination of downstream pond sediments, especially by organic pollutants. It is recommended that highway runoff should pass through a swale or detention basin prior to entering a pond.

Interpretation of data from additional study components not reported on in this paper is ongoing, and will be reported in future publications.

\section{ACKNOWLEDGEMENTS}

The work carried out at the M74 basins and the lysimeter soil core study was funded by SNIFFER. Work at the M74 basins was undertaken with permission of M6JV Group, and the authors thank Rob McLennan and staff for all assistance. Travel to sites was supported by a Carnegie Trust grant. Thanks to Alan Jones and Alan Pike (both University of Edinburgh) and Les Boyles (ADAS) for assistance with sampling.

\section{REFERENCES}

CIRIA (2007) The SUDS Manual (C697). CIRIA, London. ISBN 978-0-86017-697-8

Gray, L. 2004 Changes in water quality and macroinvertebrate communities resulting from urban stormflows in the Provo River, Utah, USA Hydrobiologia 518 33-46

Jefferies, C., Napier, F., Fogg, P. and Nicholson, F. (2008). Source Control Pollution in Sustainable Drainage. Final Report, Project UEUW01, SNIFFER, Edinburgh, Scotland.

Napier, F and Jefferies, C (2005) A Review of Vehicle-Related metals and Polycyclic Aromatic Hydrocarbons (PAHs) in the UK Environment. SEPA DPI Technical Report No. 3

National Air Emissions Inventory, available at; http://www.naei.org.uk/pollutantdetail.php

SEPA (1999) Improving Scotland's Water Environment. SEPA State of the Environment Report. Scottish Environment Protection Agency, Stirling.

Wilson, C. and Clarke, R., 2002 Persistent Pollutants in Freshwater Sediments SEPA DPI Report No. 7 